\title{
Analisa Variable Moment of Inertia (VMI) Flywheel pada Hydro-Shock Absorber Kendaraan
}

\author{
Hasbulah Zarkasy, Harus Laksana Guntur \\ Jurusan Teknik Mesin, Fakultas Teknologi Industri, Institut Teknologi Sepuluh Nopember (ITS) \\ Jl. Arief Rahman Hakim, Surabaya 60111 Indonesia \\ e-mail: haruslg@me.its.ac.id
}

\begin{abstract}
Abstrak-Flywheel selama ini dimanfaatkan untuk menyimpan energi mekanik pada mesin, membuat mesin berputar dengan lebih lembut. Prinsip kerja dari flywheel adalah dengan memanfaatkan momen inersia. Baru-baru ini dilakukan penelitian lebih lanjut mengenai pemanfaatan dari flywheel, yakni pada sistem suspense, akan tetapi selama ini penelitian yang dilakukan terbatas pada flywheel dengan momen inersia yang konstan (Constant Moment of Inertia). Kali ini akan dilakukan penelitian mengenai Variable Moment of Inertia Flywhel atau dengan kata lain flywheel yang momen inersianya berubah-ubah. Flywheel ini terdiri dari dua bagian utama, yakni flywheel berongga dan slider yang dapat bergerak bebas di sepanjang guide track. Percobaan bertujuan untuk mengetahui bagaimana karakteristik gaya redam dari VMI Flywheel. Juga akan dianalisa seperti apa respon dinamis dari slider selama flywheel berputar. Selain itu respon dinamis kendaraan saat VMI Flywheel ini dipasangkan juga dianalisa. Hasil yang didapat menunjukkan bahwa variasi massa slider berpengaruh terhadap gaya redam yang dihasilkan oleh VMI Flywheel. Semakin besar massa slider, gaya redam yang muncul juga semakin besar. Faktor frekuensi input juga berpengaruh, sebab semakin besar frekuensi input yang pada shock absorber, gaya redam yang timbul juga membesar. Perpindahan yang dialami oleh slider juga tergantung pada jenis massa slider tersebut. Semakin besar massa slider, perpindahan yang dialami juga akan semakin besar. Performa VMI Flywheel secara umum pada frekuensi rendah. Sedangkan pada frekuensi tinggi, performa VMI Flywheel cenderung tidak bagus dan menyebabkan kendaraan tidak nyaman.
\end{abstract}

Kata Kunci-Flywheel, quarter car, respon dinamis, kenyamanan kendaraan.

\section{Pendahuluan}

$\mathrm{P}$ erkembangan teknologi menuntut ide-ide kreatif untuk terus dimunculkan. Beragam inovasi teknologi telah berhasil mengatasi permasalahan-permasalahan yang muncul, tak terkecuali inovasi pada suspensi. Berbagai jenis suspensi telah dikembangkan, mulai dari passive suspension, semi-active suspension dan active suspension. Ketiganya memiliki cara kerja yang berbedabeda dan memiliki keunggulan masing-masing. Suspensi adalah alat yang berfungsi sebagai peredam kejut. Energi kinetik dari getaran atau kejut akan diserap dan diubah menjadi bentuk energi yang lain seperti panas dan bunyi ${ }^{[1]}$. Pada kendaraan, sebuah suspensi biasanya terdiri dari dua bagian utama yaitu sistem hidrolis yang di dalamnya terdapat fluida kerja dan pegas.
Semi-active suspension merupakan jenis suspensi yang harga koefisien dampingnya dapat diubah sesuai dengan kebutuhan. Performa jenis suspensi ini lebih baik dibanding dengan passive suspension yang harga koefisien dampingnya konstan, sehingga pergerakan dari kendaraan ditentukan oleh permukaan jalan. Gambar 1 akan menjelaskan mengenai perbedaan passive suspension, active suspension dan semi-active suspension.

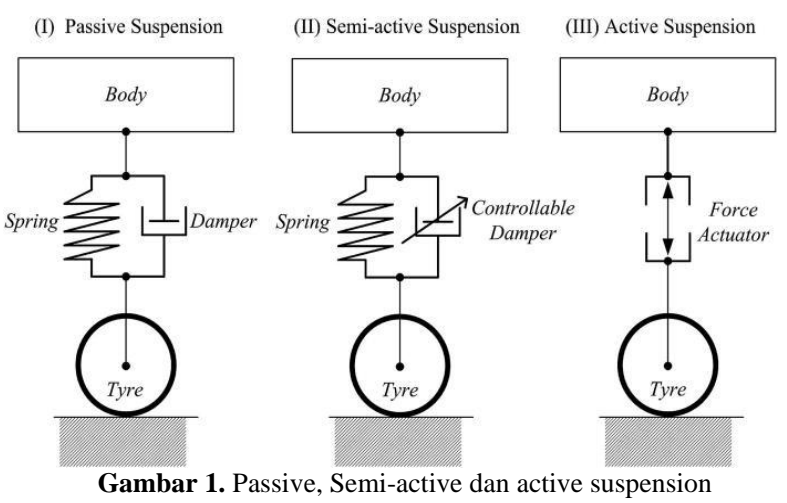

Penelitian ini ditujukan untuk pengembangan lebih lanjut mengenai salah satu semi-active suspension, yakni aplikasi dari VMI Flywheel pada hydro-shock absorber kendaraan. VMI Flywheel adalah flywheel yang memiliki momen inersia tidak konstan. Flywheel ini terdiri dari tiga bagian utama seperti yang tampak pada gambar 2, yakni flywheel, slider dan pegas. Prinsip kerja dari VMI Flywheel ini adalah ketika flywheel berputar, slider akan mengembang disebabkan oleh gaya sentrifugal. Mengembangnya slider akan merubah harga momen inersia dari flywheel.

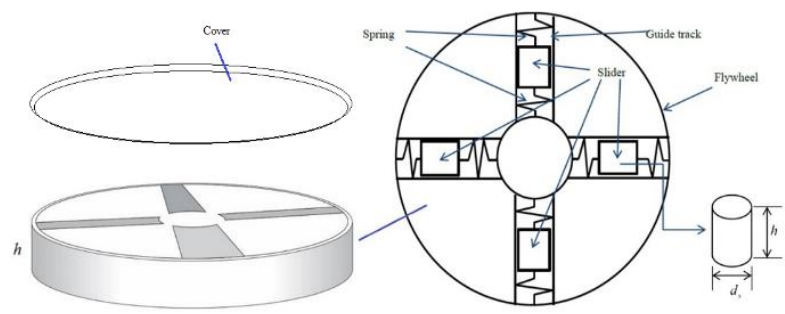

Gambar 2. Struktur VMI Flywheel

VMI Flywheel ini akan dipasangkan pada hydro-shock absorber, sebuah sistem suspensi yang memanfaatkan pressure drop akibat dari viscous damping dan headloss yang dialami oleh fluida selama suspensi bekerja sebagai peredam kejut 


\section{Metode Penelitian}

Penelitian ini dilakukan dengan menggunakan analisa simulasi menggunakan perangkat lunak Matlab. Sebelum dilakukan proses simulasi, akan dilalui beberapa tahap diantaranya proses pemodelan sistem, baik sistem supensi, slider maupun sistem seprempat kendaraan. Setelah itu adalah tahap pembuatan persamaan gerak, dan yang terakhir sebelum melangkah ke tahap simulasi, yakni tahap penyusunan blok diagram.

Pada penelitian ini, dilakukan variasi pada beberapa parameter, diantaranya frekuensi input dan massa jenis slider. Tujuan dari divariasikannya parameter ini adalah untuk melihat seperti apa pengaruhnya pada karakteristik gaya redam dari sistem suspensi. Variasi parameter tersebut akan dijelaskan pada tabel 1 di bawah ini.

TABEL 1. VARIASI PARAMETER

\begin{tabular}{ccccc}
\hline \hline Bahan & $\begin{array}{c}\text { Massa Jenis } \\
\left(\mathbf{k g} / \mathbf{m}^{\mathbf{3}}\right)\end{array}$ & $\begin{array}{c}\text { Volume } \\
\left(\mathbf{m}^{\mathbf{3}}\right)\end{array}$ & $\begin{array}{c}\text { Massa } \\
(\mathbf{k g})\end{array}$ & $\begin{array}{c}\text { Frekuensi } \\
(\mathbf{H z})\end{array}$ \\
\hline Aluminium & 2700 & $6.28 \times 10^{-6}$ & 0.016 & $0.1 ; 0.5 ; 1 ; 1.5 ; 2$ \\
Titanium & 4500 & $6.28 \times 10^{-6}$ & 0.0282 & \\
Baja & 8000 & $6.28 \times 10^{-6}$ & 0.0502 & \\
\hline \hline
\end{tabular}

Secara garis besar, penelitian terbagi menjadi tiga tahap, yaitu:

\section{A. Tahap Analisa Sistem Suspensi}

Pada tahap ini akan dianalisa sistem suspensi dengan penambahan VMI Flywheel. Sistem suspensi yang dimaksud terdiri dari bebrapa bagian, diantaranya piston, pipa saluran fluida, valve, motor hidrolik dan flywheel.

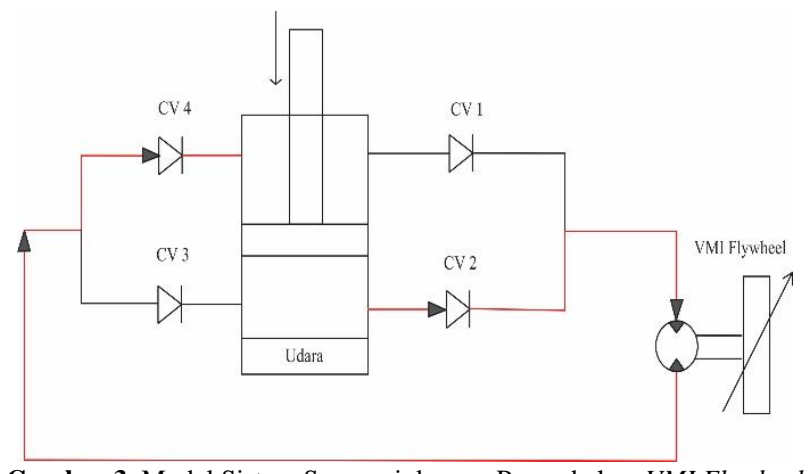

Gambar 3. Model Sistem Suspensi dengan Penambahan VMI Flywheel

Prinsip kerja dari sistem suspensi ini adalah, ketika piston bergerak naik atau turun, fluida akan terdorong dan mengalir di sepanjang pipa. Fluida tersebut akan memutar motor hidrolik yang kemudian memutar flywheel. Fungsi valve adalah menjaga agar aliran fluida ke motor hidrolik tetap searah. Gaya redam pada sistem ini dihasilkan dari pressure drop akibat perubahan luas penampang sistem hidrolik, head loss, dan efek inersia dari motor hidrolik serta flywheel. Analisa gaya redam tersebut dapat dicari:

1. Gaya Redam Akibat Sistem Hidrolik ${ }^{[2]}$

$$
F_{d}=\frac{\rho}{2} A_{1} v_{1}^{2}\left(\left(\frac{A_{1}}{A_{\text {tube }}}\right)^{2}-1\right)
$$

2. Gaya Redam Akibat Head Loss ${ }^{[2]}$

$$
F_{d}=\rho\left(\frac{32 L v}{d_{\text {tube }}{ }^{2}} \dot{x}+\frac{K}{2} \dot{x}^{2}\right) A_{1}
$$

3. Gaya Redam Akibat Motor Hidrolik

$$
F d=J \cdot \frac{\eta_{v}}{\eta_{m} \cdot q^{2}} Q \cdot A_{1}
$$

4. Gaya Redam Akibat Momen Inersia

$$
\Delta P \cdot q \cdot \eta_{m}=J \ddot{\theta}
$$

\section{B. Tahap Analisa Slider}

Pada tahap ini yang akan dianalisa adalah slider. Slider merupakan bagian yang sangat penting dari VMI Flywheel, karena merupakan kunci dari berubahnya harga momen inersia flywheel. Sistem slider pada VMI Flywheel terdiri dari sebuah massa berbentuk silinder kecil dan dua buah pegas, seperti tampak pada gambar 4 .

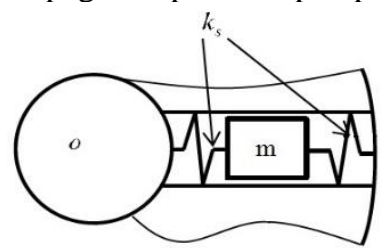

Gambar 4. Model Fisik Slider

Slider dapat bergerak dengan bebas selama flywheel berputar. Pergerakan ini disebabkan oleh gaya sentrifugal yang timbul pada slider. Saat gaya sentrifugal muncul, gaya ini akan mendorong slider ke luar pusat putar, mengakibatkan slider memberi momen inersia tambahan pada flywheel. Untuk lebih jelasnya akan ditunjukkan pada gambar 5 .

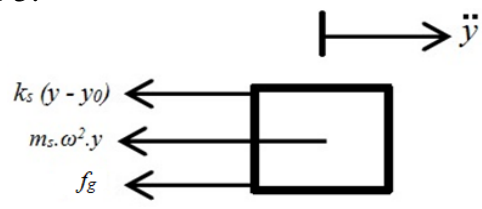

Gambar 5. Free Body Diagram Slider pada Saat Flywheel Berputar

Seperti yang dapat dilihat pada gambar di atas, gaya sentrifugal akan mendorong slider ke arah luar pusat putar. Akan tetapi, slider akan tertahan oleh gaya pegas yang menariknya kembali menuju pusat putar. Akibatnya, slider akan bergerak harmonik. Dari free body diagram di atas akan dapat diperoleh persamaan gerak dari slider, yakni

$$
\begin{gathered}
\Sigma F y=m_{s} \cdot a_{y} \\
-k_{s}\left(y-y_{0}\right)-m_{s} \cdot \omega^{2} \cdot y-f_{g}=m_{s} \cdot a_{y} \\
m_{s} \cdot\left(\omega^{2} \cdot y+a_{y}\right)+k_{s}\left(y-y_{0}\right)+f_{g}=0 \\
\text { C. Tahap Analisa Sistem Seperempat Kendaraan }
\end{gathered}
$$

Sistem seperempat kendaraan yang dimaksud merupakan model two degree of freedom. Model matematis system ini terdiri dari massa sprung, massa unsprung, koefisien kekakuan sprung, koefisien kekakuan unsprung, koefisien redaman unsprung, dan sprung, dan redaman dari sistem suspensi itu sendiri. Sistem seperempat kendaraan ini nantinya akan diberi dua buah input, yakni input sinusoidal dengan variasi frekuensi yang telah disebutkan sebelumnya dan amplitudo $2 \mathrm{~cm}$, serta input berupa bump modified dengan amplitudo $3 \mathrm{~cm}$. Akan dilihat bagaimana respon dinamis dari sistem seperempat kendaraan ini ketika dipasangkan pada suspense. Model dinamis dari sistem seperempat kendaraan ini dapat dilihat pada gambar 6 .

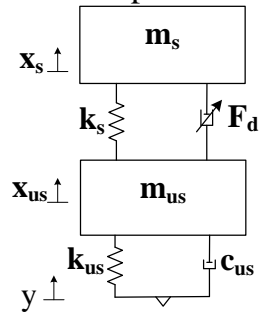

Gambar 6. Model Dinamis Sistem Seperempat Kendaraan 
Dari model dinamis di atas akan dapat diperoleh persamaan gerak sistem seperempat kendaraan tersebut, yaitu:

$$
\begin{aligned}
& \ddot{x}_{s}=\frac{1}{m_{s}}\left[-F_{d}-k_{s}\left(x_{s}-x_{u s}\right)\right] \\
& \ddot{x}_{u s}=\frac{1}{m_{u s}}\left[-c_{u s}\left(\dot{x}_{u s}-y_{\text {Jalan }}\right)-k_{u s}\left(x_{u s}-y_{\text {jalan }}\right)+\right. \\
& \left.F_{d}+k_{s}\left(x_{s}-x_{u s}\right)\right]
\end{aligned}
$$

\section{URAIAN PENELITIAN}

Pada penelitian ini akan berfokus untuk mengetahui pengaruh massa jenis slider dan frekuensi kerja pada karakteristik gaya redam dari sistem suspensi VMI Flywheel. Hasil yang ditampilkan merupakan pengolahan data hasil simulasi Matlab dalam bentuk kuantitatif dan kualitatif. Data kuantitatif akan disajikan dalam bentuk tabel, sedangkan data kualitatif akan disajikan dalam bentuk grafik.

1) Analisa Pengaruh Massa Jenis Slider terhadap Karakteristik Gaya Redam VMI Flywheel
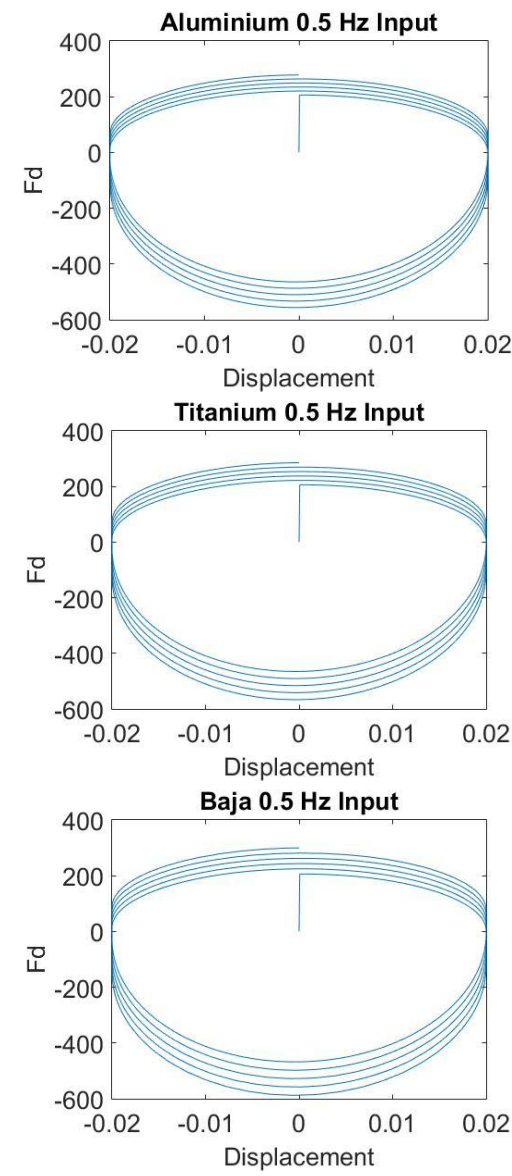

Gambar 7. Karakteristik gaya redam sistem suspensi VMI Flywheel fungsi perpindahan untuk bahan slider alumunium, titanium, baja

Sistem VMI Flywheel memiliki karakteristik gaya redam yang unik dibanding sistem suspensi biasa, yakni untuk satu input frekuensi dan satu input massa, gaya redam yang dihasilkan semakin lama semakin besar. Hal ini dikarenakan slider yang terus terdorong ke luar pusat putar seiring berputarnya flywheel akan memperbesar gaya redam hingga harga maksimum yang dapat dicapai. Setelah kondisi maksimum tersebut, gaya redam akan bernilai konstan. Dapat dilihat pada grafik di atas, gaya redam milik VMI Flywheel nampak mengembang. Karakteristik yang sama juga nampak pada grafik gaya redam fungsi kecepatan di bawah ini.
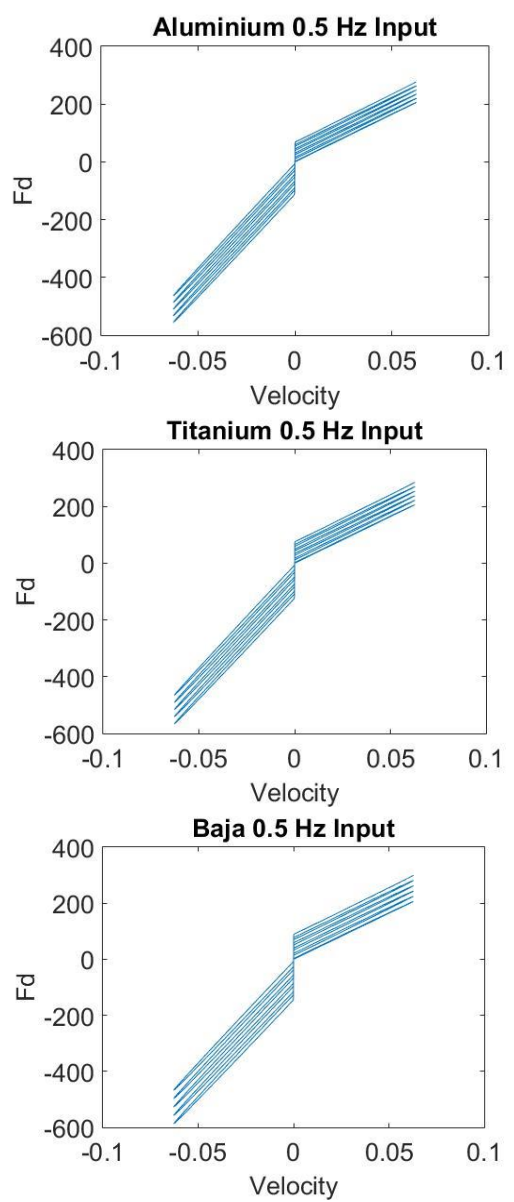

Gambar 8. Karakteristik gaya redam sistem suspensi VMI Flywheel fungsi kecepatan untuk bahan slider alumunium, titanium, baja

Hasil yang ditunjukkan oleh grafik menunjukkan bahwa pemilihan massa slider dari bahan baja menghasilkan gaya redam terbesar. Hal ini disebabkan karena semakin berat massa slider, gaya sentrifugal yang diterima juga akan semakin besar. Besarnya gaya sentrifugal ini akan mendorong slider lebih jauh yang mana akan berujung dengan semakin besarnya momen inersia total dari flywheel. Semakin besar momen inersia, akan semakin besar gaya redam yang dihasilkan. Sehingga dapat ditarik kesimpulan bahwa hasil simulasi sesuai dengan teori yang ada. Perbandingan harga gaya redam ditampilkan pada tabel di bawah ini.

TABEL 2. PERBANDINGAN HARGA GAYA REDAM

\begin{tabular}{cccc}
\hline \hline Bahan & Massa & $\Delta$ Fd Eks & $\Delta$ Fd Komp \\
\hline Aluminium & $0.016 \mathrm{~kg}$ & $52.4 \mathrm{~N}$ & $-92 \mathrm{~N}$ \\
Titanium & $0.02826 \mathrm{~kg}$ & $72.2 \mathrm{~N}$ & $-101.3 \mathrm{~N}$ \\
Baja & $0.05024 \mathrm{~kg}$ & $93.4 \mathrm{~N}$ & $-119.8 \mathrm{~N}$ \\
\hline \hline
\end{tabular}

Slider yang mengalami perpindahan lebih besar untuk massa yang lebih besar juga ditunjukkan pada grafik di bawah ini.

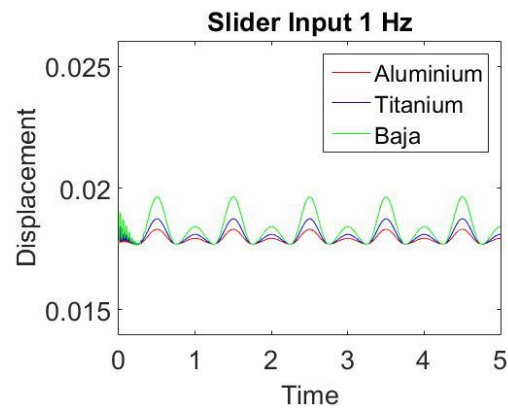

Gambar 9. Respon dinamis massa slider untuk variasi massa 
2) Analisa Pengaruh Frekuensi Kerja terhadap Karakteristik Gaya Redam VMI Flywheel
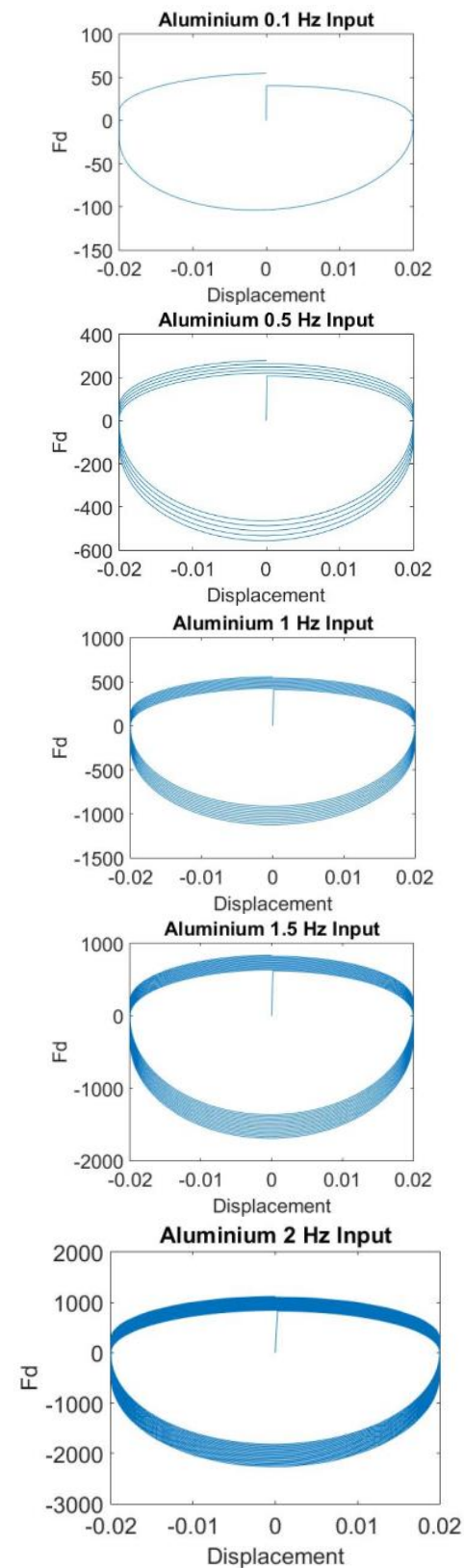

Gambar 10. Karakteristik Gaya redam VMI Flywheel untuk variasi frekuensi untuk variasi bahan slider alumunium, titanium, baja

Hasil yang ditunjukkan oleh grafik menunjukkan bahwa semakin besar frekuensi input yang diberikan akan menghasilkan gaya redam yang lebih besar. Hal ini disebabkan karena semakin cepat putaran flywheel, gaya sentrifugal yang diterima juga akan semakin besar. Besarnya gaya sentrifugal ini akan mendorong slider lebih jauh yang mana akan berujung dengan semakin besarnya momen inersia total dari flywheel. Semakin besar momen inersia, akan semakin besar gaya redam yang dihasilkan. Sehingga dapat ditarik kesimpulan bahwa hasil simulasi sesuai dengan teori yang ada.

Perpindahan slider yang makin besar seiring dengan semakin besarnya frekuensi kerja, dapat dilihat pada gambar di bawah ini.
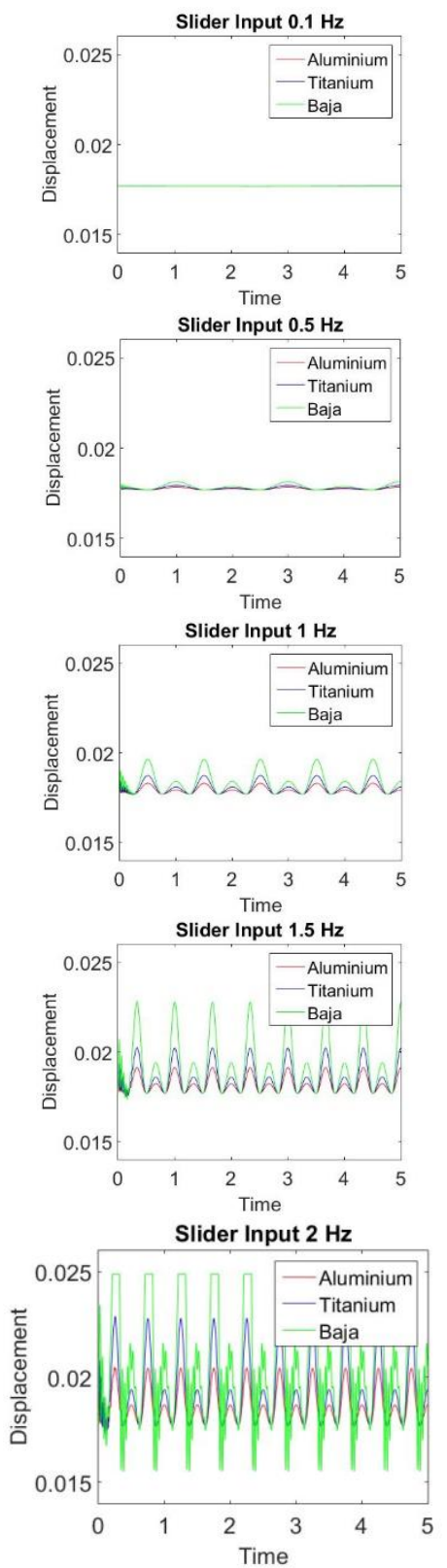

Gambar 11. Respon dinamis massa slider untuk variasi frekuensi

3) Analisa Pengaruh Massa Slider terhadap Respon Dinamis Sistem Seperempat Kendaraan

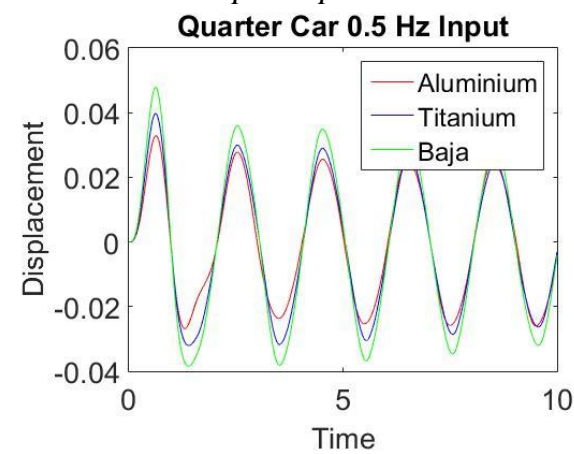

Gambar 12. Respon dinamis massa sistem seperempat kendaraan untuk variasi massa slider

Hasil yang ditunjukkan oleh grafik menunjukkan bahwa variasi massa slider pada VMI Flywheel tidak memberikan perubahan yang cukup signifikan pada respon dinamis kendaraan. Perbedaan yang terlihat hanyalah pada besar perpindahan yang dialami oleh massa kendaraan, di mana pemilihan massa slider dari bahan baja menghasilkan perpindahan terbesar, karena semakin berat massa slider, gaya redam yang dihasilkan 
juga akan lebih besar. Gaya redam ini akan ditransmisikan ke body kendaraan.

4) Analisa Pengaruh Frekuensi Kerja terhadap Respon Dinamis Sistem Seperempat Kendaraan
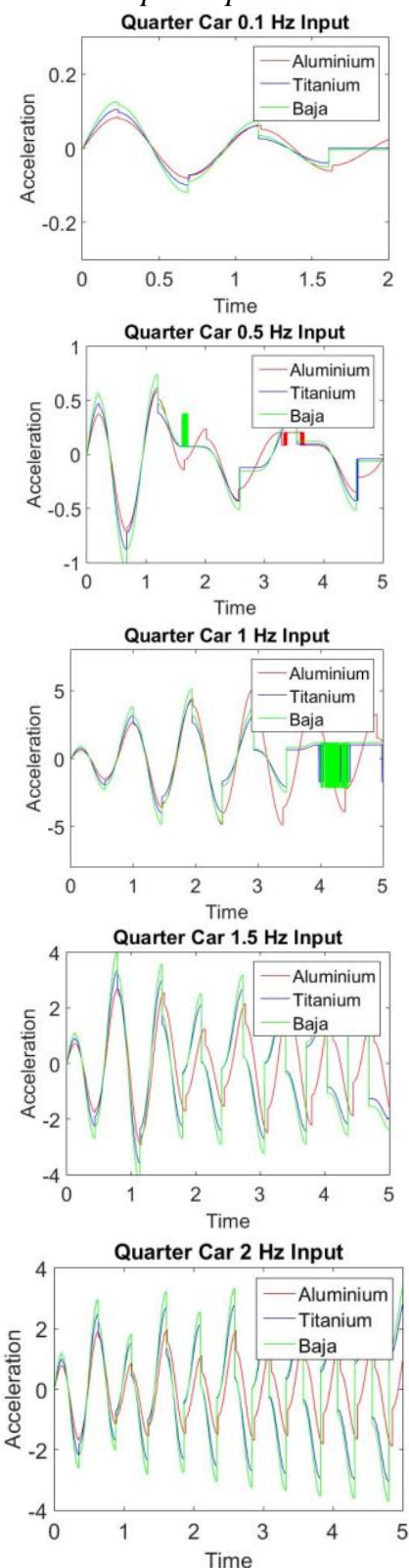

Gambar 13. Respon dinamis massa seperempat kendaraan untuk variasi frekuensi

Dari grafik di atas, dapat disimpulkan bahwa VMI Flywheel disimpulkan nyaman untuk frekuensi rendah, karena berdasar standar yang ada, kendaraan dikatakan tidak nyaman apabila memiliki rms percepatan di atas 1 $\mathrm{m} / \mathrm{s}^{2}$. Harga percepatan massa kendaraan pada frekuensi di bawah $1 \mathrm{~Hz}$ adalah kurang dari $1 \mathrm{~m} / \mathrm{s}^{2}$, sehingga dengan ini disimpulkan nyaman. Sedangkan untuk frekuensi di atas $1 \mathrm{~Hz}$ berada di atas $2 \mathrm{~m} / \mathrm{s}^{2}$. Hal ini dikarenakan untuk frekuensi rendah, perubahan gaya redam yang terjadi pada VMI Flywheel tidak terlalu besar. Sehingga gaya redam yang ditransmisikan ke massa kendaraan juga tidak signifikan.

5) Analisa Respon Dinamis Sistem Seperempat Kendaraan pada Input Bump Modified.

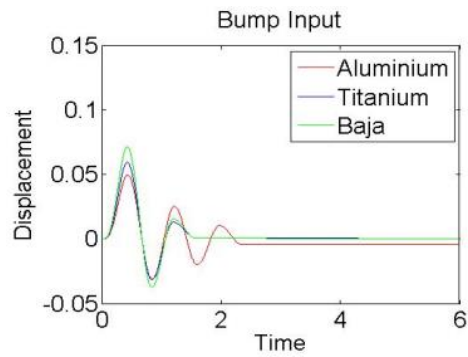

Gambar 14. Respon dinamis massa seperempat kendaraan untuk input bump modified

Hasil yang ditunjukkan oleh grafik menunjukkan bahwa pemilihan massa slider dari bahan baja menghasilkan perpindahan terbesar. Hal ini disebabkan semakin berat massa slider, gaya redam yang dihasilkan juga akan semakin besar. Gaya redam yang besar akan ditransmisikan ke massa kendaraan, menyebabkan massa tersebut berpindah dengan perpindahan yang besar juga. Untuk massa slider berupa aluminium, settling time nya lebih lama dibanding massa slider berupa titanium dan baja. Untuk baja dan titanium memiliki settling time yang mirip yakni 1.8 sekon, sedangkan massa aluminium settling time nya di atas 2 sekon.

\section{PENUTUP}

Berdasar analisa dan pembahasan yang dilakukan, maka didapatkan beberapa kesimpulan, diantaranya:

1. Harga gaya redam dari sistem suspensi VMI Flywheel bergantung pada massa dari slider yang digunakan. Semakin besar massa slider, gaya redam akan semakin besar.

2. VMI Flywheel memiliki karakteristik gaya redam yang unik, yakni dengan semakin besarnya gaya redam yang muncul dengan satu buah input. Akan tetapi gaya redam ini tidak muncul apabila frekuensi kerjanya terlalu kecil. Pada penelitian ini, untuk frekuensi $0.1 \mathrm{~Hz}$, karakteristik itu tidak terjadi.

3. Besar frekuensi akan memperngaruhi harga gaya redam yang dihasilkan oleh sistem suspensi dengan VMI Flywheel. Semakin besar frekuensinya, gaya redam akan semakin tinggi.

4. Perpindahan yang dialami oleh slider bervariasi, tergantung pada jenis bahan dan frekuensi kerja yang diberikan. Slider dengan massa baja berpindah lebih jauh daripada slider dengan massa Titanium dan Aluminium.

5. Kendaraan yang terpasang sistem suspensi dengan VMI Flywheel cenderung stabil dan lebih nyaman pada frekuensi rendah $(0.1 \mathrm{~Hz}$ sampai $1 \mathrm{~Hz})$.

\section{UCAPAN TERIMA KASIH}

Ucapan terima kasih kepada Jurusan teknik Mesin FTI-ITS yang telah memberikan dukungannya terhadap penelitian ini, dan ucapan terima kasih kepada semua pihak yang telah mendukung penulis dalam pengumpulan data dan penyusunan laporan penelitian ini.

\section{DAFTAR PUSTAKA}

[1] Rao, Singiresu S. 2010. Mechanical Vibration 5th Ed. N.J.:Prentice Hall.

[2] Fox and McDonald. 2011. Introduction to Fluid Mechanics 8th Edition. John Wiley and Sons, Inc. 